\title{
The Knowledge of People About the Use of Renewable Energy and Environmental Awareness in Their Area, Irbid Governorate as a Case Study
}

\author{
Samia Ayyoub Salim Ayyoub ${ }^{1 *}$, Nuha Mahmoud Mesleh Radaydeh² \\ ${ }^{1}$ Faculty of Architecture Engineering Department, Hijjawi Faculty for Engineering Technology, Yarmouk University, Irbid \\ 21163, Jordan \\ ${ }^{2}$ Faculty of Electrical Power Engineering Department, Hijjawi Faculty for Engineering Technology, Yarmouk University, Irbid \\ 21163, Jordan
}

Corresponding Author Email: samia.ayyoub@yu.edu.jo

https://doi.org/10.18280/ijsdp.160216

Received: 12 November 2020

Accepted: 26 January 2021

\section{Keywords:}

renewable, energy, photovoltaic cells, aesthetics, traditional, solar system

\begin{abstract}
In the global effort to curb energy consumption and promote a sustainable lifestyle for our societies, we must strive to lower our energy needs in all aspects of our lives. One of the biggest contributors to our energy requirements are the buildings we spend most of our time inside. Buildings' energy consumption can take many forms, such as, air conditioning, heating, ventilation, and lighting systems in order to create a comfortable environment for the users. One way of reducing buildings' energy consumption is the use of renewable resource for energy. The main aim of this research is to measure and assess the public perceptions, knowledge and awareness of the concept of renewable energy, with specific regards to the use of solar photovoltaic cells, as well as investigate the desire to spend on the installation of renewable energy sources. Data was collected through a survey questionnaire applied in Irbid governorate in the north of Jordan. The statistical SPSS program was used to analyze closedended questionnaires and obtain numerical results based on arithmetical averages and percentages. The results show people are adequately aware of the benefits of renewable energy and most would like to have photovoltaic cells installed. However, 54.35\% of the study sample live in apartments and do not have the space for the installation. $70.1 \%$ are open to the idea of sharing the solar energy system with their neighbors. 50\% thought that the photovoltaic cells affected the aesthetics of the architecture style of the buildings especially the more traditional styles. It is concluded that the government needs to build a large-scale solar energy project to sustainably produce electricity instead of relying on individuals who generally lack the ability or the space for such systems, taking in note that the general public supports such concepts.
\end{abstract}

\section{INTRODUCTION}

A major amount of energy is consumed by the residential sector worldwide, and the increase in the population during the last decades throughout the world is one of the main reasons for the surge in the use of energy derived from fossil fuels, with a considerable portion being employed for the heating and cooling of buildings, and as such, is considered one of the main causes for climate change and global warming [1-3]. Therefore, in order to reduce the global energy consumption, the study and analysis of the systems which allows for the reduction of energy expenditure should be our main strategy [4].

The world's energy reserve is reliant on non-renewable energy resources, meaning, it is derived from fossil fuels, which can be mined or extracted from the earth. It is formed over thousands of years from the buried leftovers of ancient plants and animals that lived millions of years ago, and as such, it is limited and will eventually run out, but more importantly it is harmful for the environment, considering that the produced carbon dioxide does not only cause air pollution but also causes heat to be trapped in our atmosphere, making it the main contributor to global warming.
On the other hand, renewable energy is derived from natural sources, such as sunlight, the wind, falling or fast-running water, tidal waves and the earth's heat (geothermal), which are often referred to as clean energy.

Energy, as it is well known, is necessary for all living creatures and the largest energy source in the world is solar radiation, which provides heat, light and energy, giving life to this planet, and without solar rays, earth's surface would have been frigid and unsuitable for life. Solar radiation is considered a major resource for sustainable and renewable energy that has been used by humanity throughout the world [5], and is expected to play a very important role, in the future, especially in developing countries [6].

Becquerel discovered the photovoltaic effect in 1839 and created the first photovoltaic cell in the early 1950s, allowing for completely new prospects for the use of solar energy to generate electricity [5].

The photovoltaic system, also known as PV, is a system which converts the sun's radiation, in the form of light, into usable electricity. The word photovoltaic comes from "photo" meaning light, while "voltaic" refers to producing electricity. Hence, the photovoltaic process "producing electricity directly from sunlight," and solar energy systems refer to technologies 
that convert sunlight into another form of energy for use. The use of solar cells allows for the capture of solar energy, which is then converted into electricity that can be used to power household appliances as well as lighting and air conditioning.

Photocells are made of a semiconductor material, usually silicon. When light hits the cell, it creates an electric field above the layers. The stronger the sun, the more electricity is generated. Cell groups are mounted in panels or modules that can be installed both on the roof or on the floor. The performance of a photovoltaic cell is measured in peak kilowatts $(\mathrm{kW})$, which is the rate at which it generates power at maximum capacity in direct sunlight in the summer. Photovoltaic cells are available in various shapes and sizes. Most PV systems are made up of panels that are installed on an existing roof.

The main disadvantage of solar energy panels is its cost, the initial cost for purchasing a solar system is high, not to mention that it takes up a lot of space. On the other hand, the advantages are that the electricity produced by solar panels is clean and quiet. With the sun being the only source used to produce electricity, photovoltaic systems do not emit harmful air pollution. In addition, solar energy is a locally available renewable resource, it does not need to be transported from one region to another nor imported from all over the world, which further reduces the environmental impact of transport as well as reduces the dependance on imported oil.

Nowadays, there is a huge variety of solar technologies and photovoltaic cells being used, but the current challenge is in finding new solutions for solar energy systems to be less capital intensive and more efficient. Several research articles are discussing such problems and highly-efficient, low-cost photovoltaic devices are being developed [6].

The main purpose of this study is to shed light on the current use of photovoltaic systems in Jordanian households and why such systems are not widely used in a country with an abundance of solar energy resources such as Jordan, as well as suggest a legal frame for the regulation and encouragement of private sector investment in renewable resources and technologies [7-11].

Jordan faces a real challenge in securing its energy supply due to the lack of indigenous energy resources which resulted in high dependence on imported energy (oil and gas) (97\% of imports in 2011). However, as Jordan moves in the direction of industrial development in order to meet the needs of the future generations, it is going to need a more reliable source of energy and renewable energy is the best candidate as a source for energy supply $[12,13]$.

\section{THE CLIMATE FACTS AND FUTURE OPPORTUNITIES IN JORDAN}

Jordan in situated in the subtropical zone located above the Tropic of Cancer at latitude of $30^{\circ} 35^{\prime}$ north and longitude of $36^{\circ} 14^{\prime}$ east.

The climate of Jordan is characterized by long, hot dry summer days and cool wet short winter days. January is the coldest month with temperatures ranging between $5^{\circ} \mathrm{C}$ and $10^{\circ} \mathrm{C}$, while August is the warmest month with temperatures ranging between $20^{\circ} \mathrm{C}$ and $35^{\circ} \mathrm{C}$. Daytime temperatures can be very high, especially in the summer, reaching $40^{\circ} \mathrm{C}$ or more on some days [14].

The number of solar days in Jordan is 316 days per year with an average of 8 hours of sunshine per day. The angle of elevation of the sun reaches 83 degrees in the summer [15].

The nature of the Jordanian climate is very suitable for the use of alternative solar energy because summer is long, and the sun shines on most winter days making it possible to take advantage of the sunlight, not to mention that Jordan is characterized by clear air most days of the year [15]. In addition, Jordan is considered one of the ideal countries located within the framework of the so-called sunbelt, which is the areas located between $36^{\circ} 30^{\prime}$ north latitude and $36^{\circ} 30^{\prime}$ south latitude with an estimated solar radiation between 5-7 1000 watts/meter square $\left(\mathrm{kWh} / \mathrm{m}^{2}\right)$ per day, with the worldwide average being $5 \mathrm{kWh} / \mathrm{m}^{2}$ per day [13]

\section{THE ENERGY SECTOR FACTS \& FUTURE ENERGY DEMAND}

The Kingdom has almost no local fossil fuel resources. It's completely dependent on foreign oil imports, and the energy sector in Jordan is struggling to meet its energy requirements, as a result, energy remains Jordan's top challenge [15]. Population increases, industrial development and a growing economy have led to a rise in the annual demand for power (Table 1), with households forming $46 \%$ of electrical energy consumption (Figure 1) [16].

Table 1. Electricity consumption (GWh)* [16]

\begin{tabular}{cccccc}
\hline & 2014 & 2015 & 2016 & 2017 & 2018 \\
\hline Household & 6580 & 6938 & 7448 & 8076 & 8038 \\
Industrial & 3877 & 4012 & 3939 & 3785 & 3877 \\
Commercial & 2358 & 2460 & 2447 & 2655 & 2507 \\
Water Pumping & 2287 & 2426 & 2485 & 2655 & 2706 \\
Street Lighting & 316 & 337 & 350 & 403 & 404 \\
Total & 15418 & 16173 & 16669 & 17574 & 17532 \\
\hline
\end{tabular}

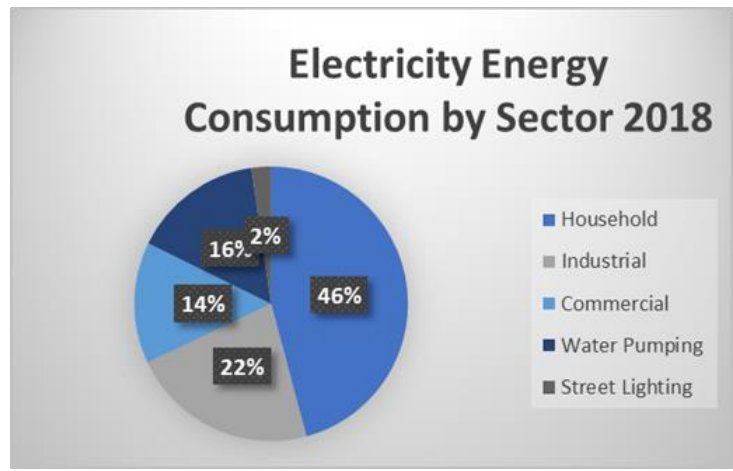

Figure 1. Electrical energy consumption by Sector in 2018 [16]

The energy sector in Jordan aims to provide energy in all its forms for all uses, at an economical cost according to the approved standards and specifications. It also aims at diversifying energy sources and forms, enhancing the security of supply, developing and exploiting renewable, local and traditional sources of energy, opening the door for private sectors to invest, improving the efficiency of the use and management of energy sources, as well as, promoting regional and Arabian energy interconnection projects and utilizing them.

The main challenges facing the energy sector in Jordan is the lack of adequate domestic sources of energy and dependence on imports, the large cost of importing crude oil 
and its derivatives considering the rapid rise in world prices and meeting the growing demand for electricity (Table 2) (Figure 2) [16].

It is important to note that Jordan has an abundance of renewable energy resources that are not being exploited efficiently, the most important of which is solar energy, considering that Jordan has natural conditions that are excellent for the use of solar energy, especially being located within the solar band of the world as well as having an abundance of clear sunny days even during the winter months.

Table 2. Energy and electricity demand forecast in Jordan [16]

\begin{tabular}{ccccccc}
\hline Year & $\begin{array}{c}\text { Electrical Energy } \\
\text { Growt }\end{array}$ & GWh & \multicolumn{2}{c}{ Max. Demand } & \multicolumn{2}{c}{ Primary Energy } \\
h\% & & MW & Growth & TOE* \\
& & $*$ & 0 & \\
\hline 2018 & -1.5 & 19755 & -3.5 & 3205 & -3 & 9712 \\
2020 & 4.3 & 21995 & 3.5 & 3676 & 3.5 & 10352 \\
2025 & 4.4 & 27285 & 3.8 & 4433 & 3 & 11943 \\
2030 & 4.4 & 338832 & 3.8 & 5341 & 3.8 & 12457 \\
\hline
\end{tabular}

Noto: *MW (megawatt is a unit for measuring power that is equivalent to one million watts); *TOE (Ton(s) of oil equivalent, abbreviated as toe, is a normalized unit of energy. By convention it is equivalent to the approximate amount of energy that can be extracted from one tons of crude oil).

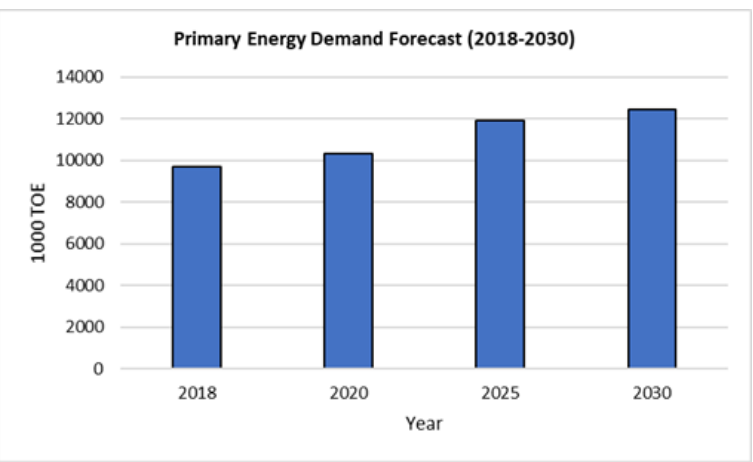

Figure 2. Primary energy demand forecast (2018-2030) [16]

\section{THE METHODOLOGY OF THE STUDY}

Energy is needed for growing food, for building the local economy with industrial developments, for securing a better reality for future generations. Inevitably, renewable energy is needed. It is continous and infinite, not to mention clean and better for our plant, and yet it is still not being utilized in its full potential, and countries such as Jordan are still reliant on imported oil even as it struggles to secure its energy requirements. With this in mind, this study was designed with goal of investigating the public's knowledge, and awareness of the concept of renewable energy, with specific regards to the use of solar photovoltaic cells, in an attempt to uncover the problems that prevent the use of solar energy in Jordan.

The study is based on a primary survey performed using a questionnaire. The questionnaire included 57 questions, divided into five sections. The first of which is focused on collecting general information about the participants, the second regards the efficiency of electricity usage, the third part asks about the participants' general knowledge regarding renewable energy, the fourth part is concerned with the benefits of renewable energy as well as the problems it faces in Jordan, and the fifth part mentions some methods to increase renewable energy utilization. The research is based on an inferential research design which has been conducted in Irbid governorate and was carried out from September 2019 until December of the same year.

The sample was collected randomly and was comprised of 399 participants. The sample size was selected through the following formula:

$$
n=\frac{N}{1+N\left(e^{2}\right)}
$$

where, $n=$ number of sample size, $N=$ number of population size (Irbid Governate holds a population of 1.77 million inhabitants (2015) [12], $e=$ the sampling error percentage of $(5 \%)$.

If we put the value of population size and sampling error, then we will get a sample size of 399.9 .

$$
n=\frac{1,770,000}{1+1,770,000(0.0025)}, n=399.9
$$

The questionnaire included selected questions designed to highlight the awareness and the knowledge regarding renewable energy use, and was randomly distributed to academic and non-academic participants. To maximize validity, the researchers explained the purpose of the study to all respondents as well as assisted the participants by explaining any questions that may have been unclear so as to ensure a uniform understanding among all participants.

The IBM SPSS Statistics software (version 25.0) was used to analyze these closed-ended questionnaires and obtain numerical results and correlation matrices based on arithmetical averages and percentages [9, 17-19].

\section{THE RESULTS OF THE QUESTIONNAIRE ANALYSIS}

What is the level of awareness regarding renewable energy in Jordanian societies? Does the level of awareness regarding renewable energy in the study sample differ according to age, occupation, and academic level......etc.? And what are the most important obstacles and challenges facing the use of renewable energy for generating electricity? These are some of the questions this study aims to answer.

It also aims to shed light on the reality of the availability of photovoltaic cells at the house level as well as offer ways so as to increase their distribution. It offers a review of the laws, regulations and legislations related to the energy sector in general and renewable energy in particular in addition to a discussion regarding the aesthetic effect that photovoltaic cells have on the architecture style of building, especially traditional buildings.

The field survey was conducted in Irbid government, a city situated to the north of the Jordanian kingdom. The study population was randomly selected and consisted of five categories: university students, researchers, academics as well as public and private sector employees. The total sample size included 399 participants.

The five sections of the questionnaire are:

\subsection{General information}

The study's population consisted of a random sample of 399 participants, of which, $48.6 \%$ were between 20-30 years old, $32.9 \%$ were between $30-40$ years old, $17.1 \%$ were between 40 60 years old and $1.5 \%$ were over 60 years old (Table 3 ). 
The percentage of holders of a bachelor's and a master's degrees was $74.3 \%$ and $7.1 \%$ respectively, $7.1 \%$ carried a $\mathrm{PhD}$, $4.3 \%$ a Diploma and $7.2 \%$ carried a high school degree or less (Table 4). Of the study population, $35.8 \%$ are collage students, $57.1 \%$ are employees, $3.0 \%$ own a business, $1.8 \%$ are not working and $2.3 \%$ are retired (Table 5).

About $60 \%$ of participants live in the city and about $40 \%$ live in the surrounding villages.

About $34.3 \%$ have their own private flats, while $20 \%$ live in rented flats and about $42.8 \%$ own their houses while $2.9 \%$ live in rented houses. $68 \%$ of those houses have an area that is between $100-200 \mathrm{~m}^{2}, 23.2 \%$ have an area that is more than $200 \mathrm{~m}^{2}$ and $8.6 \%$ have an area that is less than $100 \mathrm{~m}^{2}$.

A positive correlation is found between the age of the participants and the knowledge regarding solar energy [(Pearson Correlation) $\mathrm{r}=0.07, \mathrm{n}=395$, (sig. (2-tailed) $\mathrm{p}=0.566$ ], but there is no correlation between the level of education and the knowledge regarding solar energy or the use of photovoltaic cells $[\mathrm{r}=-0.016, \mathrm{n}=388, \mathrm{p}=0.896]$.

$55.7 \%$ of the participants don't have solar energy panels installed in their houses and $37 \%$ use solar heaters while only $2 \%$ use photovoltaic cells. Most participants who are not using solar energy, stated that if they had the opportunity to install a solar energy system, they would choose to install the photovoltaic cells system.

Table 3. Age of the participants

\begin{tabular}{ccccc}
\hline Age/Year & Frequency & Percent & $\begin{array}{c}\text { Valid } \\
\text { Percent }\end{array}$ & $\begin{array}{c}\text { Cumulative } \\
\text { Percent }\end{array}$ \\
\hline $20-30$ & 194 & 48.6 & 48.6 & 48.6 \\
$30-40$ & 131 & 32.8 & 32.9 & 81.5 \\
$40-60$ & 68 & 17.0 & 17.1 & 98.6 \\
$>60$ & 6 & 1.50 & 1.4 & 100 \\
Total & 399 & 100 & 100 & \\
\hline
\end{tabular}

Table 4. level of education

\begin{tabular}{ccccc}
\hline $\begin{array}{c}\text { Level of } \\
\text { Education }\end{array}$ & Frequency & Percent & $\begin{array}{c}\text { Valid } \\
\text { Percent }\end{array}$ & $\begin{array}{c}\text { Cumulative } \\
\text { Percent }\end{array}$ \\
\hline $\begin{array}{c}\text { High school } \\
\text { or less }\end{array}$ & 28 & 7.2 & 7.2 & 7.2 \\
$\begin{array}{c}\text { Bachelor's } \\
\text { Degree }\end{array}$ & 296 & 74.3 & 74.3 & 81.5 \\
Master's & 29 & 7.1 & 7.1 & 88.6 \\
degree & 29 & 7.1 & 7.1 & 95.7 \\
PhD & 17 & 4.3 & 4.3 & 100 \\
$\begin{array}{c}\text { Diploma } \\
\text { Total }\end{array}$ & 399 & 100.0 & & \\
\hline
\end{tabular}

Table 5. Type of work for the participants

\begin{tabular}{ccccc}
\hline $\begin{array}{c}\text { Type of } \\
\text { Work }\end{array}$ & Frequency & Percent & $\begin{array}{c}\text { Valid } \\
\text { Percent }\end{array}$ & $\begin{array}{c}\text { Cumulative } \\
\text { Percent }\end{array}$ \\
\hline Student & 143.0 & 35.8 & 35.8 & 35.8 \\
Employee & 228.0 & 57.1 & 57.1 & 92.9 \\
Free & 12.0 & 3 & 3 & 95.9 \\
Business & & & & \\
Not & 7.0 & 1.8 & 1.8 & 97.7 \\
working & 9.0 & 2.3 & 2.3 & 100 \\
Retired & 399 & 100 & 100 & \\
Total & & & & \\
\hline
\end{tabular}

\subsection{The efficiency of electricity usage}

$22.9 \%$ of participants use an average of 300 kilowatts $(\mathrm{kW})$ or less of electricity a month, while 44.3 use more than 300 $\mathrm{kW}$ a month, with $51.4 \%$ stating that the monthly electric bill makes up less than $15 \%$ of their monthly income, $27.1 \%$ between 15 and $30 \%, 10 \%$ between 30 and $50 \%$ and $4.3 \%$ pay more than $50 \%$ of their income for electricity.

$72.9 \%$ of participants leave the lights on during daytime, even though there is enough daylight inside the house or work place. $85.7 \%$ turn off the lights before leaving when they are the last person to leave. $34.8 \%$ completely cut off the electric current after they stop using electric devices, such as, the television or the computer, while $61.4 \%$ do not. $81.4 \%$ use LED power saving light bulbs inside their homes.

$75.7 \%$ of the participants' homes are not thermally insulated, resulting in a larger demand of energy for heating or cooling, especially taking in consideration that $74.3 \%$ of participants relied solely on electricity for such purposes. $32.9 \%$ were aware about the benefits of heat insulation, while $61.4 \%$ had no knowledge. $84.3 \%$ concede that the electric bills are becoming a burden to them, also, the programmed cut off of electric currents due to increased load in the summer season have a negative effect on their houses.

There is a positive correlation found between the monthly average of electricity usage and the square area of the living residence $[\mathrm{r}=0.304, \mathrm{n}=377, \mathrm{p}=0.039$ ], in addition, a negative correlation is found between the electricity bills being a burden on the citizens and thermally insulated houses $[\mathrm{r}=-0.201$, $\mathrm{n}=391, \mathrm{p}=0.106]$.

\subsection{General knowledge regarding renewable energy}

The level of awareness regarding renewable energy in the study sample is as such; $34 \%$ of participants $20-30$ years old are knowledgeable about renewable energy, $22 \%$ of the 30 40 -year-olds are knowledgeable while only about $12 \%$ of the 40-60-year-olds have any knowledge regarding renewable energy. $22.7 \%$ of participants stated that they did not have any knowledge regarding renewable energy. $18.6 \%$ acquired their knowledge regarding solar energy from educational resources, $38.6 \%$ from internet websites and $21.4 \%$ from other resources.

With the limited availability of public education regarding renewable energy, $25 \%$ of the participants believe that schools and universities are responsible to provide knowledge and awareness of renewable energy, while $14.7 \%$ believe it's the responsibility of television programs. $27.1 \%$ believe that this role is reliant on social media and $31.4 \%$ state that the responsibility of spreading awareness depends on all of them.

There is a positive correlation found between the awareness regarding solar energy and the knowledge that solar energy use saves money $[\mathrm{r}=0.327, \mathrm{n}=384, \mathrm{p}=0.006]$, that solar energy could be used on a large scale in Jordan $[\mathrm{r}=0.394, \mathrm{n}=386$, $\mathrm{p}=0.001]$, and the believe that the government should provide support to the people regarding the use of solar energy $[\mathrm{r}=0.301, \mathrm{n}=388, \mathrm{p}=0.014]$. There is also a positive correlation between the awareness and the installation of solar energy systems [ $\mathrm{r}=0.096, \mathrm{n}=385, \mathrm{p}=0.443$ ], as well as the knowledge of solar energy companies in the area $[r=0.270, n=379$, $\mathrm{p}=0.031]$.

\subsection{Information about the benefits of renewable energy and the problems faces}

$25.7 \%$ of the study participants believe that the use of solar energy is important for the reduction of the use of oil and its products and the reliance on foreign imports, $14.3 \%$ stated that 
solar energy is most important for the protection and safety of our environment and its survival, while $41.4 \%$ suppose that its main benefit lies in offering a permanent and a never-ending source of energy.

Although the level of awareness among Jordanians regarding the importance of using solar panels is very high, only $2.9 \%$ of the sample participants have photovoltaic cells installed in their homes, and although most are aware of the benefits of using photovoltaic cells, especially considering $94.3 \%$ believe it's our responsibility to protect the environment, and save it from pollution, $75.7 \%$ state that the high initial cost of installing a solar energy system and the poor quality of some products prevents them from purchasing on a larger scale.

The type of residential buildings and their characteristics have also affected the spread of photovoltaic cells installed in Jordan, around $54.3 \%$ of Jordanians live in apartments, and therefore have no space on the roofs of buildings for the installation of photovoltaic cells. In Jordan, water is supplied by the Ministry of Water and Irrigation to the domestic sectors once a week. It is pumped to each sector in a weekly arranged schedule, and every house and apartment must store water in a tank to be used for all the rest of the week. These tanks are usually placed on the roof, causing most building roofs to be occupied.

\subsection{Methods to increase renewable energy utilization}

About $52.9 \%$ of the survey participants are of the opinion that every house should install a solar energy system in order to generate electricity. $95.7 \%$ believe that solar energy saves money, by reducing their electrical monthly bills and $90 \%$ are of the opinion that the use of renewable energy is the most effective method to achieve this goal. $75.7 \%$ stated that they cannot afford to install solar energy systems because of the high cost of the initial installation, but $62.9 \%$ agreed that they don't mind sharing a solar energy system with their neighbors, with $67.1 \%$ willing to invest less than 1500 Jordanian Dinar (JOD) in solar energy systems, $18.6 \%$ between 1500-3000 JOD and only $5.7 \%$ willing to invest more than 3000 JOD.

$91.4 \%$ of participants stated that solar energy should be used in a larger scale in Jordan by the government in order to provide cheaper electricity for the public, and $84.3 \%$ are of the opinion that the government should build solar energy projects for mass production. Around $90 \%$ believe that there should also be some encouragement and assistance from the government by means of offering cheaper prices or insuring quality of product, wherein $95.5 \%$ agree that the government should have regulation and building guidelines to assist architects in designing buildings that are accommodating of green and sustainability systems, considering most citizens live in apartment building and don't have enough space to install solar panels on the roof.

About $85.7 \%$ of participants believe that the presence of several solar energy companies would encourage citizens to install solar energy systems, by creating a competitive environment which may drive the prices lower, and about $87 \%$ are of the opinion that if a cooperation existed between banks and solar energy companies which allows citizens to obtain loans with minimal benefits for the installation of solar energy panels, it would encourage the use of solar energy more commonly among the public. Not to mention that reducing the tax on solar cells and the materials needed for its production and installation is another method for reducing its cost, and hence, strengthen peoples' inclination, and expand the use of photovoltaic cells in Jordan.

A partnership between solar energy companies and the scientific and technological institutions would fund programs that would increase the citizens awareness of solar energy and its benefits, as well as help in providing new methods of manufacturing that may be cheaper or more efficient which will eventually lead to an increased willingness by the people to purchase and install solar panels.

A positive correlation is found between the willingness to share with the neighbors in installing a solar energy system and the high cost of such systems $[r=0.204, n=378, p=0.121]$, as well as with the desire to reduce the monthly electric bill $[\mathrm{r}=0.285, \mathrm{n}=387, \mathrm{p}=0.025]$.

\section{AESTHETIC VS ECONOMICAL FEATURES OF A HOME}

Is aesthetics more important than function or vice versa? Most people are familiar with the concept of "form follows function" but to focus too much on function can lead to a boring design and paying too much attention to aesthetics can result in a poor user experience. The decision of to which give the importance, function or aesthetics, is one of the most common challenges faced by many architects when designing a house or a building, but a great design finds balance between function and aesthetics as both are of equal importance [20].

The aesthetics and art are usually defined as an attractiveness characteristic for many traditional buildings [21]. The power of beauty lies in the design; therefore, we enjoy aesthetic designs because it satisfies our senses, it brings us joy. People like to live and work in beautifully designed and aesthetically pleasing places [22]. An aesthetic design is important not only to create a first impression, but also to strengthen the relationship between the building and the user [23]. To ignore aesthetics for the sake of economic reasons or any other practical considerations will rob the user from this joy and this relationship [20, 24].

On the other hand, the current architectural style in Jordan does not take into consideration the elements of renewable energy such as, photovoltaic cells, and in order to utilize this energy in Jordan there is a need to install these elements as an addition to the buildings' design, as a result this might reduce the aesthetical value of the buildings or contradict traditional architectural elements which may result in aesthetically unpleasing buildings.

Therefore, the question remains, upon which our attention and focus should be placed, the preservation of the heritage buildings and the traditional architectural style in Jordan or the utilization of renewable energy for a greener future for Jordan.

\section{CONCLUSION AND RECOMMENDATIONS}

With energy being one of Jordan's most challenging problems, especially, as it tries to grow a more independent economy by moving further towards industrial development, it stands to reason that it would rely on utilizing its abundant natural resources for renewable energy, with solar power being at the forefront, considering its aforementioned excellent conditions as well as ideal location, although surprisingly, this is not the case. Jordan remains trapped in a continues struggle to provide its own energy requirements, and as such, is still almost fully dependent on oil imports, foreign countries and 
global prices. With this in mind, came the question; how much do the citizens know about renewable energy? How much are they aware of its benefits? And if they are aware, why aren't they installing it? What is the reason standing in their way?

It was realized, through this study, that although Jordanian communities have a limitation regarding the public's education about renewable energy through the media or within schools, they do not, however, lack in their understanding and awareness regarding renewable energy and its importance, either in its direct benefits to the people, by reducing the cost of the electric bills or in its indirect benefits to the environment, in fact, many are of the opinion that solar energy panels are a necessity in every household and are keen on installing it in their own houses. The true problem is that most Jordanian citizens cannot afford the high costs of installing a solar energy system and those who can, do not have enough space on the roofs of their buildings, which are already filled with water tanks. It is important to note here that the majority of citizens in Jordan live in apartment buildings, with single houses belonging mostly to the rich or to people living in villages outside the cities.

One solution was proposed and was met with enthusiasm, which is that one solar energy system would be installed on the roof of apartment buildings, which would be shared equally between the residents. The costs would be divided equally between the neighbors, and everyone would benefit from the solar energy being produced. The government could play a part in this regard as well, for if there were a regulation that requires every building to have a solar energy system installed which distributes to all the apartments, it would cause the use of solar energy to spread country wide and eventually cause a reduction in the annual demand for energy, in addition, architects would be required to take solar energy panels in consideration while designing buildings, and as a result create enough space for it in advance.

Another method to increase the population's inclination to invest in solar energy panels is by offering methods that would enable the citizens to afford these systems, for example, banks could offer special loans with minimal benefits that people could use to install solar energy panels or the government could lower the tax on solar energy panel imports or on the materials needed for its manufacture and installation which would result in a reduction in its cost, and consequently, an increase in demand. There are also the solar energy companies themselves, for if these companies were to fund scientific research institutes, there may be new methods discovered for manufacturing or installation that may require less expenses, not to mention that these companies play an important role in further educating and increasing the awareness of the citizens regarding solar energy benefits and its importance.

Lastly, a large solar energy project could be set up in Jordan, with the goal of producing electricity in a massive scale to be distributed for the entire country. It would reduce the annual demand on foreign oil imports as well as provide the citizens with cheaper electricity, which would allow the county to prosper on two regards, the reduction in the resources reserved for securing the country's energy requirements would allow the government to redirect those funds elsewhere, likewise, the reduction in their electrical expenses, would allow the citizens to utilize those savings in improving their own economic situation or possibly invest, which would eventually become a part of the country's economic development. It is important to note that a large portion of Jordan's area in covered in desert, mostly to the east, and this area is mostly baren, unutilized, uninhibited land, with a clear, sunny, hot weather most days of the year, with little to no rain, making it an ideal location for such a large-scale solar project.

Although the size of the sample of participants in this study was correlated with the population size of Irbid governorate, where our research took place, and the distribution of participants in regards to age, education and living conditions was comparable to the population at large, it was felt that a larger sample would have given a more powerful assessment of the results, furthermore, considering the variations between the life styles of the people living in different parts of the country, repeating the survey in different cities, or including participants from different cities in a bigger study sample would have also further reinforced the results of the study, and as such, these points are considered the main limitations of this research. It is also worth noting that special questionnaires and interviews with government officials, solar energy companies' owners and workers as well as scientists in the field are a proposed scheme for a subsequent study.

\section{ACKNOWLEDGEMENT}

The authors would like to express their sincere gratitude to all who have participated in the questionnaire of this study as well as to Muna Ma' ayah who assisted the authors in editing this article.

This research did not receive any specific grants from funding agencies in the public, commercial or non-profit sectors.

\section{REFERENCES}

[1] Synnefa, A., Santamouris, M., Akbari, H. (2007). Estimating the effect of using cool coatings on energy loads and thermal comfort in residential buildings in various climatic conditions. Energy and Buildings, 39(11):

$1167-1174$ https://doi.org/10.1016/j.enbuild.2007.01.004

[2] Fraas, L. (2014). Low Cost Solar Electric Power. Switzerland: Springer International. https://doi.org/10.1007/978-3-319-07530-3_1

[3] Mutani, G., Todeschi, V. (2019). An urban energy atlas and engineering model for resilient cities. International Journal of Heat and Technology, 37(4): 936-947. https://doi.org/10.18280/ijht.370402

[4] Mansouri, O., Boubia, F. (2019). The Influence of the envelope color on energy consumption. International Conference on Contemporary Affairs in Architecture and Urbanism pp. 64-71 (ICCAUA-2019, Proceedings of the 2nd International Conference of Contemporary Affairs on Architecture and Urbanism (ICCAUA2019), Alanya HEP University, Alanya, Turkey.

[5] Sen, Z. (2004). Solar energy in progress and future research trends. Progress in Energy and Combustion Science, 30(4): 367-416. https://doi.org/10.1016/j.pecs.2004.02.004

[6] Zyadin, A., Puhakka, A., Ahponen, P., Pelkonen, P. (2014). Secondary school teachers' knowledge, perceptions, and attitudes toward renewable energy in Jordan. Renewable Energy, 62: 341-348. https://doi.org/10.1016/j.renene.2013.07.033

[7] Benchikh, O. (2001). Global renewable energy education 
and training programme (GREET Programme). Desalination, 141(2): 209-221. https://doi.org/10.1016/S0011-9164(01)00406-4

[8] Çelikler, D. (2013). Awareness about renewable energy of pre-service science teachers in Turkey. Renewable Energy, 60: 343-348. https://doi.org/10.1016/j.renene.2013.05.034

[9] Freije, A.M., Hussain, T., Salman, E.A. (2017). Global warming awareness among the University of Bahrain science students. Journal of the Association of Arab Universities for Basic and Applied Sciences, 22: 9-16. https://doi.org/10.1016/j.jaubas.2016.02.002

[10] Amjad, K. (2020). Perception and knowledge on climate change: A study of private university students in Bangladesh. Environmental and Earth Sciences Research Journal, 7(2): 62-66. https://doi.org/10.18280/eesrj.070202

[11] Zou, D.Z., Sun, C. (2020). Analysis for thermal performance and energy-efficient technology of prefabricated building walls. International Journal of Heat and Technology, 38(1): 269-273. https://doi.org/10.18280/ijht.380129

[12] Ministry of Energy \& Mineral. (2019). Energy 2019Facts \& Figures. www.memr.gov.jo.

[13] Mojahed Elsagheer. (2013). Energy Situation in Jordan, Ministry of Planning and International Cooperation, Jordan, IEEJ: July 2013. https://eneken.ieej.or.jp/data/5020.pdf2013.

[14] Online, W. (1999-2020). Weather online. Retrieved from https://www.weatheronline.co.uk/reports/climate/Jordan .htm.

[15] Royal scientific Society. (n.d.). Retrieved from http:/www.rss.jo/.

[16] Ministry of Energy \& Mineral, www.memr.gov.jo.

[17] Abdul Rahim, N. (2015). The Energy Sector in Jordan Brussels Invest \& Export Embassy of Belgium Beirut Lebanon August 2015 www.silo.tips_the-energy-sectorin-jordan.pdf.

[18] Statistics 2015, Department of Statistics. Retrieved (2019). http://dosweb.dos.gov.jo/ar/.

[19] Wiesner, S., Horizonte, C.B. (2014). The development of technicians as a key factor for a sustainable development of renewable energies using an adapted education method based on the successful German Dual Education (Duale Ausbildung). Energy Procedia, (57): 1034-1036. https://doi.org/10.1016/j.egypro.2014.10.069

[20] Assali, A., Khatib, T., Najjar, A. (2019). Renewable energy awareness among future generation of Palestine. Renewable Energy, 136: 254-263. https://doi.org/10.1016/j.renene.2019.01.007

[21] Bartel, M. (1999). Ethics of Aesthetics and Design in Housing. https://www.goshen.edu/art/design/ethics.html.

[22] Selicati, V., Cardinale, N., Dassisti, M. (2020). Evaluation of the sustainability of energy retrofit interventions on the historical heritage: A case study in the city of Matera, Italy. International Journal of Heat and Technology, 38(1): https://doi.org/10.18280/ijht.380103

[23] Vinchu, A., Jirge, N., Deshande, A. (2017). Application of aesthetics in architecture and design. International Journal of Engineering Research and Technology, 10(1). http://www.irphouse.com.

[24] Lee, J.J. (2010). Home life: Cultivating a domestic aesthetic. Contemporary Aesthetics, 8(1): 15. 